\title{
E-Learning effective during the Covid-19 era
}

\author{
Ilham Tri Maulana*, STMIK Indonesia Padang,Indonesia, ilhamtm@stmikindonesia.ac.id, ORCID 0000- \\ 0001-7613-4492 \\ Fadil Firdian, STMIK Indonesia Padang, Indonesia, fadilfirdian@stmikindonesia.ac.id, ORCID 0000-0002- \\ 1170-2927
}

Liranti Rahmelina, STMIK Indonesia Padang, Indonesia, lirantirahmelina@stmikindonesia.ac.id, ORCID 0000-0002-8126-4325

Sri Restu Ningsih, STMIK Indonesia Padang, Indonesia, srirestuningsih@stmikindonesia.ac.id, ORCID 00000003-2610-6893

Karmila Suryani, Bung Hatta University, Indonesia, karmila.suryani@bunghatta.ac.id,ORCID 0000-00018466-5138

Restu Amelia Putri, Student, STMIK Indonesia Padang, Indonesia, restuameliaputri47@gmail.com, 00000002-2126-9805

\begin{abstract}
The purpose of this study is to develop a learning method using online media during the Covid19 period. This study designed an e-learning media for the Computer Network Management Design course using the Instructional Development Institute (IDI). Data were obtained from 54 students from 2 groups of 2 teaching staffs. The test results showed that the results of the effectiveness test of this study have a very effective level of $94.44 \%$. Therefore, it can be concluded that this e-learning media is useful in learning Computer Network Management Design during the Covid-19 pandemic. This e-learning media can be used as a reference model for other practical courses.
\end{abstract}

Keywords: Online learning, Covid-19 Pandemic, Learning Outcomes, Effectivity, Instructional Development Institute, Computer Network Management Design

Received: $16.12 .2020 \quad$ Accepted: 04.01.2021 Published: 02.02.2021

\section{INTRODUCTION}

The outbreak of Covid-19 in almost all over the world had given impact which badly affect many aspects of humankind, including in the field of education. Governments around the world, including Indonesia, must take action and make decision to maximize the use of information and communication technology in education and change the face-to-face learning method into e-learning / online learning in order to make sure that the continuity of education can be maintained. Based on the Circular Letter issued by the government of the Republic of Indonesia on March 18, 2020, all indoor and outdoor activities in all sectors are temporarily postponed to reduce the spread of Corona, especially in educational sector.

On March 24, 2020, the Minister of Education and Culture of the Republic of Indonesia issued Circular Letter Number 4 of 2020 concerning Implementation of Education Policies During Emergency Situation of Covid-19 Pandemic. The circular demands that the learning process must be carried out at home through online / distance learning in order to provide meaningful learning experiences for students. The use of information and communication technology (ICT) in online learning is a new innovation in educational realm. Technological advances have provided valuable opportunities for teaching and learning in Covid-19 era (Abuhmaid, 2020). The use of ICT greatly influences the progress of online learning innovation (Sofyan \& Hartati, 2020). The use of ICT shifts the paradigm that was originally more likely to be passive and only relies on what is provided by educators, or is still conventional, to become more active and student-oriented.

One of the universities in Indonesia currently facing the impact of the spread of Covid-19 in its educational activities is STMIK Indonesia Padang. STMIK Indonesia Padang is one of the educational institutions located in Lolong Belanti, Padang City, and is one of the higher learning institutions favored by the people in the city of Padang thanks to the quality of education that is always be maintained by STMIK Indonesia Padang. STMIK Indonesia Padang is very concerned about the quality of the campus, such as student discipline and lecturers, facilities and infrastructure, and the achievement of learning implementation plans in all subjects. Student satisfaction is the marketing concept applied by STMIK Indonesia Padang by maintaining all aspects in ensuring and improving the quality of education (Hassan \& Shamsudin, 2019). Quality must be maintained and improved to produce qualified graduates who have 
good competence and skills. One of the methods in maintaining this quality must be supported by good technological capabilities (Adri \& Ganefri, 2020).

However, the technology currently applied in the delivery of theoretical learning materials is still common, and the material for practical learning is still low. The rather low use of technology in practical lectures can be seen when learning activities mostly use social media facilities such as WhatsApp, Quizizz, and Youtube. This condition is considered ineffective in the use of e-learning media for learning subjects that require more interaction between teachers and students.

Previously the teaching staff gave lecture and assignments based on the learning schedule set by the academic administration section. The assignment given was in the form of material from the books read by the students for which the students shall answer the questions or quizzes given to them, while the teachers or lecturers did not necessarily give complete and comprehensive explanation on the subject directly to students. As a matter of fact, the cognitive aspects of learning are closely related to the ability of the students in developing their thinking and mental processes in intellectual activities (Omar \& Mohamad, 2019), without which the students cannot explore their potential because of the lack of iterative explanation. If this problem is not resolved quickly, it will create an impact in the form of depreciation of learning outcomes and inability to achieve learning objectives with excellent quality.

One of the practical subjects that must be mastered by the students of STMIK Indonesia Padang is Computer Network Management Design. The subject is directed at improving the design and management capabilities of computer networks. In consideration of the importance of mastering computer network management design by a computer science graduate, this learning outcome must receive full attention, especially during the Covid-19 era. Based on data from the teaching staff, there were only 32 students in the mid-semester exam who passed the Minimum Completion Criteria (KKM) and achieved grade 75, which means it was only $60 \%$ of the active students (source: teaching staff of Computer Network Management Design subject).

In view of such disturbing data on the learning outcome, it is necessary to create an innovative learning model to boost the achievement of the students, namely by adopting e-learning method and utilizing information and communication technology. The solution to the above problems is to develop active learning in the form a learning model using E-learning that is valid, practical and effective. Learning and studying by means of e-learning has become the method of educational technology and teaching theory that must be used in the Covid-19 pandemic (Chen \& Chen, 2020).

The use of learning media using e-learning can improve the quality of learning outcome and trigger the creativity and active role of the students. Ee-learning helps the students to have an earlier opportunity to obtain learning material. E-Learning also provides the skills needed to prepare the students for a more complex living and working environment during the Covid-19 pandemic (Aksu \& Eser, 2020). E-Learning makes it easier for the students to learn independently and to choose material according to their wishes in the concept of independent learning (Kemendikbud, 2020).

In Covid-19 pandemic era like today, the teaching staff must be able to trigger active learning. Active learning is mediated by the educators by involving the wisdom of the educators in such a way that it shall transmit the knowledge and at the same time transform the learners reflectively (Vieira \& Silva, 2020). The educators need to understand the differences in the application of active learning because it can have a significant effect on the psychology and learning capability of the learners (Rahim \& Shamsudin, 2019). The application of active learning requires the ability of teachers to design and develop the media and learning models that can help either the teachers and the students in the learning process.

The success of education will be achieved by setting standard goals and tasks, acting strategically while monitoring and revising the processes and the results, using appropriate technological tools, and productively addressing the challenges they face (Jin Michael Splichala, Jun Oshimac, 2018). Diversity in developing online learning media can be used as the strategy for an active learning of today (Yunus \& Omar, 2020). In addition, the educators should make more changes to their teaching methods when they have more opportunities to use technology in online learning (Sung \& Chang, 2016). Development of digital technology creates innovations in learning models that can happen when it is done online (Krismadinata \& Verawardina, 2020). Online learning using computers/laptops can be used not only as games, entertainment and the internet, but also as the concrete tools for the students to tacke current problems such as problem solving, logic development, and critical thinking during the learning process using E-learning (Coşar \& Özdemir, 2020).

The program used in the development of practical learning in e-learning at STMIK Indonesia Padang is the Learning Management System (LMS) Moddle. E-learning embraces two main areas, namely learning and technology (Ningsih \& Effendi, 2019). The results of the study clearly describe the perceptions of the educators and the students in their needs for technology-based innovation (Chauhan \& 
Sagar, 2020). The development of learning media using E-Learning in online learning allows the teachers to create and adapt to the existing curriculum (Sari \& Zulaiha, 2020).

Management of the learning process using e-learning which is developed through this LMS can become a learning medium that can cover various activities of the teaching staff and the students such as uploading files, downloading materials, quizzes, and exercises which are expected to be in accordance with the needs of the learning process at STMIK Indonesia Padang. In addition, Student satisfaction is important in assessing the success of the online learning process using E-learning because it is directly related to the quality of online learning and student learning outcomes (Susilana \& Hutagalung, 2020). Elearning uses videos to present teaching discussions and create up-to-date ideas in improving the skills of the students (Rahmelina \& Maulana, 2019).

\section{METHODS}

This research adopts research and development (R\&D) method as the guideline for design and development process. The development model being used is that of IDI (Instructional Development Institute) model. IDI applies the system development principles approach which is suitable for the research in learning. The IDI model establishes the principles of design and development process which includes three stages, namely definition, development and evaluation stages (Maulana \& Firdian, 2019).

The Definition Stage contains the steps to identify problems, analyze curriculum and learning models, analyze student characteristics, analyze learning concepts/materials and analyze learning models. The Development Stage contains the preparation of the initial form (prototype) of the model and the validation of the collaborative learning model. The Evaluation (Assessment) Stage contains the steps of testing and analyzing of the results of the research by analyzing the questionnaire on a Likert scale previously distributed to the students.

\section{Data Collection Instruments}

Validity

Validity instrument is used to determine the level of validity of online learning using the elearning developed in this research. The e-learning is validated by the experts and the lecturers of the subject. The validation being tested are those related to content and design. The scale being used in compiling the validation instrument in this research is that of Likert scale in which at this scale the variables to be measured shall be translated into variable indicators.

Practicality

Practicality instrument is used to determine the level of practicality of online learning using the E-learning developed in this research. The practicality of the e-learning is tested based on the responses of the students and the teaching staff. The scale being used is that of Likert scale in which at this scale the variables to be measured shall be translated into variable indicators.

\section{Effectiveness}

Effectiveness of the research can be measured from the grades achieved by the students attending the E-learning. The learning outcome is obtained from the examination given to the students involved in the online learning using E-learning which has been made valid and practical. The passing grade for the examination shall be $>75$.

\section{Technical Data Analysis}

To analyze the data, the method to be employed shall be descriptive data analysis. Descriptive data analysis technique is used to explain the level of validity, practicality and effectiveness of the online learning using E-learning as implemented to the subject: computer network management design.

Validity analysis (Maulana \& Firdian, 2020).

Steps for data validity analysis:

The validators sets multiple choice answers with the following criteria:

- 5 = very valid, $4=$ valid, 3 = fairly valid, 2 = less valid, $1=$ not valid.

- Counting all the scores given by the validator on each question indicator.

- The formula used for fixing the percentage of data validity analysis:

$$
\text { Percentage }=\ldots \text { S Score of each items } \times 100 \%
$$




\section{$\sum$ Score of ideal items}

Table 1 shows the scoring level and category of data validity analysis

Table 1. Scoring level of validity (Maulana \& Firdian, 2020).

\begin{tabular}{ccc}
\hline No & Scoring Level (\%) & Category \\
\hline 1 & $90-100$ & Very valid \\
2 & $80-89$ & Valid \\
3 & $65-79$ & Fairly Valid \\
4 & $55-64$ & Less Valid \\
5 & $0-54$ & Not Valid \\
\hline
\end{tabular}

Practicality Analysis (Maulana \& Firdian, 2019).

Steps for data practicality analysis:

The validators sets multiple choice answers with the following criteria:

- $5=$ very valid, $4=$ valid, $3=$ fairly valid, $2=$ less valid, $1=$ not valid.

- Counting all the scores given by the validator on each question indicator.

- The formula used for fixing the percentage of data practicality analysis:

$$
\text { Percentage }=\frac{\sum \text { Score of each items }}{\sum \text { Score of ideal items }} \times 100 \%
$$

Table 2 shows the the scoring level and category of data practicality analysis

Table 2. Scoring level of practicality (Maulana \& Firdian, 2019).

\begin{tabular}{ccc}
\hline No & Scoring Level (\%) & Category \\
\hline 1 & $90-100$ & Very Practical \\
2 & $80-89$ & Practical \\
3 & $65-79$ & Fairly Practical \\
4 & $55-64$ & Less Practical \\
5 & $0-54$ & Not Practical \\
\hline
\end{tabular}

Table 3 shows the the scoring level and category of data effectiveness analysis

Table 3. Scoring level of effectiveness (Maulana \& Firdian, 2020)

\begin{tabular}{ccc}
\hline No & Scoring Level (\%) & Category \\
\hline 1 & $90-100$ & Very Effective \\
2 & $80-89$ & Effective \\
3 & $65-79$ & Fairly Effective \\
4 & $55-64$ & Less Effective \\
5 & $0-54$ & Not Effective \\
\hline
\end{tabular}

The applied standard which serves as the indicator of success in learning outcome shall be the Passing Grade (Minimum Completion Criteria) which is 75 (source: the lecturers of the subject of study: Computer Network Management Design)

\section{RESULTS}

\section{Obtaining validity test data}

The data obtained validity is shows in Table 4: 
Table 4. Acquisition of validity tests from experts

\begin{tabular}{cccc}
\hline Validation Aspects & $\begin{array}{l}\text { Total } \\
\text { Score }\end{array}$ & $\begin{array}{l}\text { Validity Value } \\
\mathbf{( \% )}\end{array}$ & Criteria \\
\hline E-Learning Content & 47 & 85.45 & Valid \\
E-Learning Design & 52 & 86.67 & Valid \\
\hline Total Score/ Validity Value/ Category & 110 & 86.06 & Valid \\
\hline
\end{tabular}

Based on Table 4, the data on the results of the validity test of online learning using E-learning for the practical course of computer network management design. Validation of online learning using Elearning for the content aspect gets a valid value (85.45\%). Validation of online learning using E-learning for the design aspect gets a valid value (86.67\%). On average, all results of validation of online learning using E-learning for content and design aspects get a valid value (86.06\%). Online learning using Elearning for the practical course of computer network management design is declared valid as a learning medium during the Covid 19 pandemic.

\section{Obtaining practicality test data}

\section{a. Practicality Test Data from Lecturers}

Data on the acquisition of practicality tests from the teaching staff can be shows in Table 5 as follows:

Table 5: Acquisition of practicality tests from the teaching staff

\begin{tabular}{|c|c|c|c|c|}
\hline \multirow{2}{*}{ Measurement section } & \multicolumn{3}{|c|}{ Total } & \multirow{2}{*}{ Criteria } \\
\hline & R1 & R2 & Average & \\
\hline Ease of Use & 45 & 90 & 67.5 & Fairly Practical \\
\hline Time Effectiveness & 45 & 70 & 57.5 & Less Effective \\
\hline Media interpretation & 90 & 95 & 92.5 & Very Practical \\
\hline Equivalence & 40 & 90 & 65 & Fairly Practical \\
\hline Average & 55 & 86.25 & 70.62 & Fairly Practical \\
\hline
\end{tabular}

R1 = Lecturer 1 R2 = Lecturer 2

Based on Table 5, data on the practicality test results of online learning using E-learning for the practical course of computer network management design based on the responses of the teaching staff. The practicality of online learning using E-learning for aspects of the ease of use of E-learning gets a fairly practical value (67.50\%). The practicality of online learning using E-learning for the aspect of time effectiveness of teaching staff using E-learning is less practical (57.50\%). The practicality of online learning using E-learning for the interpretation aspects of E-Learning gets a very practical value $(92.50 \%)$. The practicality of online learning using E-learning for the equivalence aspect gets quite practical value (65\%). On average, all results of the validation of online learning using E-learning for the four aspects get a fairly practical value (70.62\%). Online learning using E-learning for the practical course of computer network management design is stated to be quite practical as a learning medium based on assessments from teaching staff during the Covid 19 pandemic.

\section{b. Pacticality Test Data Based on Student Responses}

Data on the acquisition of practicality tests from students can be shows in Table 6 as follows:

Table 6. Recapitulation of practicality test acquisition from students

\begin{tabular}{lll}
\hline \multicolumn{1}{c}{ Measurement section } & Penjumlahan & Criteria \\
\hline Simplicity of E-Learning users & 78.14 & Fairly Practical \\
Time effectiveness of using E-Learning & 71.85 & Fairly Practical \\
The appeal of using E-Learning & 79.75 & Fairly Practical \\
\hline Average & $\mathbf{7 6 . 5 8}$ & Fairly Practical
\end{tabular}

Based on Table 6, the data on the practicality of online learning using E-learning for the practical course of computer network management design is based on the responses of students. The practicality of online learning using E-learning for aspects of the simplicity of using E-learning gets a fairly practical 
value (78.14\%). The practicality of online learning using E-learning for the time effectiveness aspect of students using E-learning gets a fairly practical value $(71.85 \%)$. The practicality of online learning using E-learning for aspects of the attractiveness of using E-learning gets a fairly practical value $(79.75 \%)$. On average all the results of validation of online learning using E-learning for all three aspects get a fairly practical value (76.58\%). Online learning using E-learning for the practical course of computer network management design is stated to be quite practical as a learning medium based on the assessments of students during the COVID-19 pandemic..

\section{Effectiveness}

The acquisition of the effectiveness test of student learning outcomes can be shows in Table

7 (source: teaching staff of Computer Network Management Design subject).

Table 7. Acquisition of effectiveness test data

\begin{tabular}{|lc|}
\hline & Total Students \\
\hline Student Pass & Student not pass \\
\hline 51 student $(94.44 \%)$ & 3 student $(5.56 \%)$ \\
\hline
\end{tabular}

Based on Table 7, the data on the results of the online learning effectiveness test using E-learning is based on the learning outcomes of students. The number of students who passed online learning using Elearning for the practical course of computer network management design was 51 people with the very effective category $(94.44 \%)$. Meanwhile, the number of students who did not pass online learning using E-learning for the practical course of computer network management design totaled 3 people $(5.56 \%)$. Online learning using E-learning for the practical course of computer network management design is stated to be very effective as a learning medium during the Covid 19 pandemic.

\section{DISCUSSION and CONCLUSIONS}

1. Discussion of the validity test results

Validity is the accuracy and accuracy of measuring instruments to perform its measurement functions (Maulana \& Firdian, 2020). The aspects that are measured by experts to test the validity of online learning using E-learning are aspects of the content and design of E-learning. Before measuring the validity of the content and design aspects, the statement indicators used were validated. The results of the questionnaire validation assessment of the content aspect statement indicator from the expert get a valid value $(85 \%)$. The results of the questionnaire validation assessment of the design aspect statement indicators from experts get a very valid value (90\%). Based on the results of this validation, it can be concluded that the aspects used to measure the validity of online learning using E-learning, the practical course of computer network management design are precisely and carefully used for measuring the validity of using E-learning for online learning during the Covid 19 era.

Instruments that are valid for this aspect of the content are then given to the E-learning expert for assessment. The number of statement indicators in the content aspect is 11 items. Of the 11 statement items, they were divided into 2 major groups, namely the content and interest groups. From the content group, experts directly assess the learning material uploaded to E-learning. The uploaded material is adjusted between the learning outcomes of students and the semester learning plan. In this section the expert also assesses whether the learning material is in accordance with the learning objectives. In the interest group, experts assess characteristics and increase students' interest in learning using E-learning.

The final result of the expert's assessment, for the content aspect, it gets a valid average value (84.44\%). This means that the learning material uploaded to E-learning is valid between the learning achievements of students and the semester learning plans. In this section the learning material is valid / valid with the learning objectives. The final result of the expert's assessment, for the aspect of interest, the average score is very valid (90\%). This means that online learning using E-learning is very suitable for the characteristics of students. In this section the use of E-learning is very valid to increase students interest in learning. Overall, the average value of the content aspect is valid (85.45\%).

The next valid instrument is a questionnaire instrument for aspects of online learning design using E-learning. The very valid questionnaire was given to E-learning experts for assessment. The total of statement indicators in the design aspect is 12 items. Of the 12 statement items, they were divided into 2 major groups, namely the instructional design group and the appearance of E-learning and the language used in E-learning. From the instructional media design group, E-learning experts directly assess the instructions, color composition and appearance of E-learning that are interesting to use. In this section the expert also assessment whether the functioning of the menus available on E-learning is going well. In 
the language group, E-learning experts assess whether the language used is easy and simple to understand and is in accordance with the enhanced spelling

The final result of the expert's assessment, for the aspects of instructional design and the appearance of E-learning, gets a valid average value $(84 \%)$. This means that the instructions, color composition and appearance of E-learning are valid for use by students. In this section the functionality of the menus available on E-learning is valid. The final result of the expert's assessment, for aspects of the language used in E-learning get a valid average value (80\%). This means that the language used in online learning using E-learning is easy and simple for students to understand and is in accordance with the enhanced spelling. Overall, the use of E-learning for online learning during the Covid 19 pandemic was valid $(86.06 \%)$ for use by teaching staff and students for the practical course on computer network management design.

\section{Discussion of practicality test results}

Practicality relates to the practicality of implementing online learning using developed media and is equipped with clear instructions to make it easier for users. The practicality of using online learning using E-learning is measured based on the response of the teaching staff and students who carry out the practical courses of computer network management design. Before conducting an assessment of the practicality of using E-learning for online learning during the Covid 19 pandemic, first validation of each statement indicator used by E-learning experts. This validation process is carried out to determine the validity of each questionnaire statement given to the teaching staff and students.

The results of the assessment of the E-learning experts on the validity of the practicality questionnaire of the statement indicators being asked get a valid value (85\%). Based on the results of the validation from the E-learning expert, it can be concluded that the questionnaire instrument used to determine the response of teaching staff and students to the use of E-learning for the practical course of computer network management design is appropriate and valid to use. The valid questionnaire is then given to the teaching staff for filling in. The filling out of the practicality questionnaire was filled based on their response / experience using E-learning in the online computer network management practical course during the Covid 19 pandemic era. The practicality questionnaire based on the lecturers responses was divided into 4 major groups, namely their response to the ease of using E-learning, the effectiveness of the time used, the interpretation of E-learning and the E-learning equivalence.

From the aspect of the convenience of lecturers in using E-learning online during the Covid 19 pandemic, the average value is quite practical (65.60\%). This means that E-learning developed for online learning is quite easy / practical enough for the teaching staff to use. From the aspect of the effectiveness of the time used in using online E-learning during the Covid 19 pandemic, the average value is less practical (57.50\%). This means that E-learning developed for online learning in terms of time effectiveness is less practical for teaching staff. The less of practical effectiveness of this time is because the lecturers must just adapt in managing the time for the practical learning process in using E-learning during the Covid 19 pandemic. It is hoped that in the next semester the lecturers will be able to manage the time to use online E-learning during the Covid 19 pandemic effectively.

From the interpretive aspect of using E-learning online during the Covid 19 pandemic, the average value is very practical $(92.50 \%)$. This means that E-learning developed for online learning is very practical / very easy to understand for operation by the teaching staff. From the equivalence aspect of using E-learning online during the Covid 19 pandemic, the average value is quite practical (65\%). This means that E-learning developed for online learning is quite practical / quite comparable to other learning media. So that it can be used as a variety of effective and efficient learning media. In this questionnaire the teaching staff also conducted an overall assessment using online E-learning in the computer network management design practical course. Overall the use of online E-learning by teaching staff in the practical course of computer network management design gets practical value (80\%). This means that E-learning which is used by the teaching staff for practical courses on computer network management design online is practical to use.

The valid questionnaire is then given to students for filling in. The filling out of the practicality questionnaire was filled based on their response / experience using E-learning in the online computer network management practical course during the Covid 19 pandemic. Practicality questionnaires based on student responses were divided into 3 major groups, namely their response to the ease of using Elearning, the effectiveness of using E-Learning and the attractiveness of using E-learning. From the aspect of the ease of students in using E-learning online during the Covid 19 pandemic, the average value is quite practical (78.14\%). This means that E-learning developed for online learning is quite easy / practical enough for students to use. 
From the aspect of the effectiveness of the time used in using online E-learning during the Covid 19 pandemic, the average value is quite practical (71.85\%). This means that E-learning developed for online learning in terms of time effectiveness is quite practical for students to use. In terms of the attractiveness of using online E-learning during the Covid 19 pandemic, the average value is quite practical (79.75\%). This means that E-learning developed for online learning is quite interesting to use by students. Overall the use of online E-learning by students in the practical course of computer network management design gets practical value (86.66\%). This means that E-learning used by students for practical courses on computer network management design online during the Covid 19 pandemic is practical to use.

\section{Discussion of effectiveness test results}

Effectiveness can be applied if the learning media developed is valid and practical. Learning media is said to be effective if the results are as expected. The effectiveness of using E-learning online during the Covid 19 pandemic for the computer network management design course can be seen from the results of the final semester exam. Based on the results of the final semesters that have been carried out, as many as 51 people (94.44\%) students passed and passed the minimum criteria. Meanwhile, the total of students who did not pass was $3(5.56 \%)$. If we compare the number of students passing before and after using online learning using E-learning, it increased by 29 people (54.44\%). The use of online learning using Elearning also reduces the number of students who do not pass by 29 (55.44\%). Based on the effectiveness test table category, the use of E-learning for online learning in the practical course of computer network management design during the Covid 19 pandemic is in the very effective category.

Based on the results of the discussion about the validity above, it can be concluded that the validity of the E-learning learning media developed for online learning during the COVID-19 era from the content aspect gets a valid value (85.45\%). This means that the E-learning content section is valid for use as an online learning medium during covid 19. The validity of the E-learning learning media developed for online learning during the Covid 19 pandemic from the design aspect gets a valid value (86.67\%). This means that from the E-learning design section it is valid to be used as an online learning medium when Covid 19. Overall, both of these aspects received a valid value (86.06\%). This means that E-learning learning media are valid to be used as online learning media during Covid 19 in terms of content and design.

Based on the results of the practicality discussion above, it can be concluded that the overall practicality of E-learning learning media developed for online learning during the COVID-19 pandemic from the response of the teaching staff gets practical value $(80 \%)$. This means that from practicality Elearning is practically used as an online learning medium when Covid 19. In terms of students, as a whole, the practicality of E-learning learning media developed for online learning during the COVID-19 pandemic, the responses of students get practical value $(86.66 \%)$. This means that from practicality Elearning is practically used as an online learning medium when covid 19 by students. Overall, both of these aspects received a valid value (83.33). This means that practical E-learning learning media to be used as online learning media during Covid 19 is based on the responses of teachers and students.

Based on the results of the discussion of the effectiveness above, it can be concluded that the Elearning learning media developed for online learning during the COVID-19 pandemic based on student learning outcomes is very effective. E-learning learning media developed was proven to improve student learning outcomes, as evidenced by 51 people (94.44\%) students passing and passing the minimum criteria set in the semester learning plan.

This study has provided references using online E-learning media during the COVID-19 pandemic which can be used in practical learning of computer network management design. This research can provide input to education providers, because the media developed can improve student learning outcomes. The teaching staff can use this learning media so that its use is not only limited to computer network management design materials but can be used for other learning. For other researchers to develop similar things in other subjects.

\section{ACKNOWLEDGEMENT}

This work was supported by Yayasan Amal Bakti Mukmin STMIK Indonesia Padang with grand number : 007/K.A/LPPM/STMIK-I/2020. Thanks to the research team Techonolgy in Education STMIK Indonesia Padang. 


\section{REFERENCES}

Abuhmaid, A. M. (2020). The efficiency of online learning environment for implementing project-based learning: Students' perceptions. International Journal of Higher Education, 9(5), 76-83. https://doi.org/10.5430/ijhe.v9n5p76

Adri, M., \& Ganefri. (2020). Using ADDIE Instructional Model to Design Blended Project-Based Learning based on Production Approach. International Journal of Advanced Science and Technology, 29(06), 1899-1909.

Aksu, G., \& Eser, M. T. (2020). Development of analytical thinking tendency scale: Validity and reliability study. Elementary Education Online, 2307-2321. https://doi.org/10.17051/ilkonline.2020.764229

Chauhan, S., \& Sagar, V. (2020). A Study Of Organizational Supporting Factors For Acceptance Of Engagement In Technology-Enhanced Learning. International Journal of Advanced Science and Technology, 29(12), 1-8.

Chen, R., \& Chen, S. (2020). Online Cooperative Teaching Mode Based on Self-Direction Theory in Method of Sport Science Research. International Journal of Emerging Technologies in Learning (IJET), 15(22), 24. https://doi.org/10.3991/ijet.v15i22.18035

Coşar, M., \& Özdemir, S. (2020). The effects of computer programming on elementary school students' academic achievement and attitudes towards computer. Elementary Education Online, 19(3), 15091522. https://doi.org/10.17051/ilkonline.2020.732794

Hassan, S., \& Shamsudin, M. F. (2019). Measuring the effect of service quality and corporate image on student satisfaction and loyalty in higher learning institutes of technical and vocational education and training. International Journal of Engineering and Advanced Technology, 8(5), 533-538. https://doi.org/10.35940/ijeat.E1077.0585C19

Jin Michael Splichala, Jun Oshimac, R. O. (2018). Regulation of collaboration in project-based learning mediated by CSCL scripting reflection. Computers and Education, 125, 132-145. https://doi.org/https://doi.org/10.1016/j.compedu.2018.06.003

Krismadinata, \& Verawardina, U. (2020). Blended learning as instructional model in vocational education: Literature review. Universal Journal of Educational Research, 8(11B), 5801-5815. https://doi.org/10.13189/ujer.2020.082214

Maulana, I. T., \& Firdian, F. (2019). Project-based learning model practicality on local network devices installation subject. International Journal of Emerging Technologies in Learning, 14(15), 94-106. https://doi.org/10.3991/ijet.v14i15.10305

Maulana, I. T., \& Firdian, F. (2020). Development of Problem-Based Basic Computer Network Teaching Tools. Journal of Education: Theory, Research, and Development, 21, 671-676. https://doi.org/http://dx.doi.org/10.17977/jptpp.v5i5.13523

Ningsih, S. R., \& Effendi, Z. M. (2019). Implementation of cooperative learning model on E-assignment responsiveness at higher education. International Journal of Emerging Technologies in Learning, 14(18), 209-219. https://doi.org/10.3991/ijet.v14i18.10752

Omar, N., \& Mohamad, M. M. (2019). The relationship of cognitive, affective, and conative elements in problem solving process in engineering learning. Journal of Technical Education and Training, 11(2), 23-31. https://doi.org/10.30880/jtet.2019.11.02.003

Rahim, M. I., \& Shamsudin, S. (2019). Categorisation of video lecture designs in MOOC for technical and vocational education and training educators. Journal of Technical Education and Training, 11(4), 1117. https://doi.org/10.30880/jtet.2019.11.04.002

Rahmelina, L., \& Maulana, I. T. (2019). The effectiveness of the flipped classroom model using e-learning media in introduction to information technology course. International Journal of Emerging Technologies in Learning, 14(21), 148-162. https://doi.org/10.3991/ijet.v14i21.10426

Sari, Y. Y., \& Zulaiha, S. (2020). The development of a digital application to promote parents' involvement in character education at primary schools. Elementary Education Online, 19(4), 2564-2570. https://doi.org/10.17051/ilkonline.19.04.001

Sofyan, H., \& Hartati, S. (2020). Developing e-module local wisdom based for learning at kindergarten in Jambi, Indonesia. Elementary Education Online, 19(4), 2074-2085. https://doi.org/10.17051/ilkonline.2020.763331

Sung, Y. T., \& Chang, K. E. (2016). The effects of integrating mobile devices with teaching and learning on students' learning performance: A meta-analysis and research synthesis. Computers and Education, 94, 252-275. https://doi.org/10.1016/j.compedu.2015.11.008

Susilana, R., \& Hutagalung, F. (2020). Students ' Perceptions toward Online Learning in Higher Education in Indonesia during COVID-19 Pandemic. Elementary Education Online, 19(4), 9-19. 
https://doi.org/10.17051/ilkonline.2020.04.101

Vieira, C. K., \& Silva, C. N. da. (2020). Teacher knowledge as a student: socialization practices by pedagogical reflection. International Journal for Innovation Education and Research, 8(1), 205-212. https://doi.org/10.31686/ijier.vol8.iss1.2151

Yunus, F. A. N., \& Omar, N. H. M. (2020). Multimedia courseware for interactive teaching and learning: Students' needs and perspectives. Journal of Technical Education and Training, 12(1 Special Issue), 261-269. https://doi.org/10.30880/jtet.2020.12.01.028 